\title{
PASTURE RENOVATION FOR INCREASED DAIRY PRODUCTION
}

\author{
K. CHESTNUT \\ Farmer, Kokopu, Whangarei.
}

Over the past six seasons that I have been on the farm, per hectare production has increased by $140 \mathrm{~kg} / \mathrm{ha}(40 \%)$ achieved through a $38 \%$ lift in stocking rate. During this time per cow production has been maintained at a level well above the district average. Most of the increase in production has been achieved by making better use of the existing pasture through feed budgeting. However over the last two seasons I am also getting considerable benefit from my pasture-renovation programme which will continue to have an important part in my future farming programme.

\section{FARM DESCRIPTION}

I started sharemilking on the property in 1980 then purchased the farm in 1983. The farm is 62 ha (58 ha in grass) of wet gumland soils consisting of 16 ha of rolling Waikare clay and 46 ha of flat Wharekohe and Kara clays typical of about $20 \%$ of Northland.

Production has increased every year by an average of $140 \mathrm{~kg} / \mathrm{ha}$ (Table 1) and next season I intend to break the $500 \mathrm{~kg} / \mathrm{ha}$ barrier. The increase has come about by an increase in stocking rate without any decline in per cow production. In 1980/81 I thought I was fully stocked and did not think then that I would carry the stock I have now, or the production I am achieving. A lot of the increase to date has been due to feed budgeting, but over the last season in particular I am getting a lot of benefit from the pasture renovation and drainage that has been done over the last 3 seasons.

TABLE 1. Farm production over 5 years.

\begin{tabular}{lccccc}
\hline & $1980 / 81$ & $1981 / 82$ & $1982 / 83$ & $1983 / 84$ & $1984 / 85$ \\
\hline Cows milked & 115 & 120 & 132 & 143 & 159 \\
Production (kg) & 19760 & 20130 & 21480 & 24200 & 28000 \\
Kg fat/cow & 172 & 168 & 163 & 169 & 176 \\
Kg fat/ha & 340 & 347 & 370 & 417 & 483 \\
Stocking Rate (cows/ha) & $\mathbf{2 . 4 5}$ & $\mathbf{2 . 5 0}$ & $\mathbf{2 . 6 5}$ & $\mathbf{3 . 0 0}$ & 3.25 \\
\hline
\end{tabular}

\section{Techniques}

\section{PASTURE RENOVATION}

The first year I renovated some of the poorer paddocks on the farm, by under-sowing into the existing sward. During March 1982 the paddock was hard grazed first then Ellett ryegrass at $12 \mathrm{~kg} / \mathrm{ha}$ and Pitau white clover at $2 \mathrm{~kg} / \mathrm{ha}$ were drilled with a triple disc machine. In fact I did all I was supposed to do but I was disappointed with the results as there was still too much competition from the existing grasses. The seed seemed to germinate all right but not enough survived.

For the following 3 seasons I boom sprayed with 'Roundup' first in March as early as possible after the first decent autumn rain. The paddocks were then cross drilled with the same triple disc machine within 10-14 days, using a seed mixutre of Ellett ryegrass at 15 $\mathrm{kg} / \mathrm{ha}$, Moata ryegrass at $5 \mathrm{~kg}$ and Pitau white clover at $2 \mathrm{~kg} / \mathrm{ha}$. Moata was included because of the extra feed it provided during the first winter but as it did not last for 2 years as it is supposed to, Concord was used last autumn instead. It will be interesting to see how long it lasts. 
To date I have done a total of 13 ha in this way with excellent results. Most of these areas heavily infested with tall fescue were sprayed with Roundup at 5 litres/ha. Those areas with poor pasture species but no tall fescue were sprayed with Roundup at 2 litres/ha.

\section{Grazing $M$ anagement}

During the autumn and winter the new grass areas get special treatment. I make sure they do not get too long and they are not grazed when there is any chance of pugging damage. The first grazing has usually been within 4-5 weeks of sowing using 45-55 yearling heifers which get a daily break. At this stage the paddock is about IO-12 cm long. From then on the new grass is grazed every 4-5 weeks during the winter. From August onwards the paddocks are grazed by the milking cows which go wherever the feed is and the new grass areas fit in with that system.

\section{COSTS AND BENEFITS}

In previous years $I$ noticed that the new grass areas produced more grass during the first autumn and winter than the older established pastures on the farm. This benefit extended into the spring when the new pasture paddocks could be grazed by the milkers more frequently than the older pasture on the farm. During the 1985 year I was able to monitor this advantage as part of my normal feed budgeting system (Table 2). From sowing in March to September the new grass grew $40 \%$ faster than the rest of the farm. This large benefit during the first winter will be continued during the following winter, but at a lower level of about $24 \%$ advantage over the old pasture (Table 3). In the spring these new grass areas are grazed on average 4 days earlier than other paddocks meaning the new grass area would be grazed 5 times to every 4 for the rest of the farm giving an extra $20 \%$ of feed in the spring. Over the summer they also tend to be grazed more often but l have not kept records. However on an annual basis I am satisfied that the new grass areas are producing $15-20 \%$ more feed than the rest of the farm and certainly are producing a third more milking feed than the previous tall fescue infested paddocks.

TABLE 2. Comparison of growth of new grass areas with the whole farm average for winter 1985 (Sown March 19, 1985).

\begin{tabular}{|c|c|c|c|}
\hline & $\begin{array}{r}\text { Rate of } \\
\text { New }\end{array}$ & $\begin{array}{l}\text { Pasture Growth } \\
\text { Grass } \quad \text { Farm }\end{array}$ & $\begin{array}{l}\text { (kg/ha.day) } \\
\text { Average }\end{array}$ \\
\hline $19 / 3-25 / 4$ & & 40 & 35 \\
\hline $26 / 4 \quad 18 / 5$ & & 39 & 28 \\
\hline $19 / 5-4 / 6$ & & 41 & 22 \\
\hline $5 / 6-9 / 7$ & & 33 & 20 \\
\hline $10 / 7-2 / 8$ & & 21 & 14 \\
\hline $3 / 8=10 / 9$ & & 30 & 23 \\
\hline Average & & 34 & 24 \\
\hline
\end{tabular}

The extra butterfat produced on the new grass areas is estimated as follows: For the last two seasons the farm has produced $450 \mathrm{~kg}$ butterfat/ha. Allowing $24 \mathrm{~kg} \mathrm{DM} / \mathrm{ha}$ per $\mathrm{kg}$ butterfat and estimate $80 \%$ utilisation of pasture grown, then the farm over these two years produced an average of $13,500 \mathrm{~kg} \mathrm{DM} / \mathrm{ha}$. With the 13 ha renovated so far producing at least $15 \%$ more grass than the average for the rest of the farm, this equates with an extra $2,000 \mathrm{~kg} \mathrm{DM} / \mathrm{ha}$.

The new grass paddocks are therefore producing at least $15,500 \mathrm{~kg} \mathrm{DM} / \mathrm{ha} /$ year and as these paddocks before renovation were producing below the average of the farm, the extra grass produced must be in excess of $2,000 \mathrm{~kg} \mathrm{DM} / \mathrm{ha}$. Nevertheless, taking the extra 2,000 $\mathrm{kg} \mathrm{DM} / \mathrm{ha}$ of pasture as equivalent to an extra $67 \mathrm{~kg}$ butterfat/ha. I am satisfied that on fescue paddocks I cover my costs in the first year while on the poorer pastures with no fescue there is a worthwhile profit within the first season (Table 4). 
TABLE 3. Comparison of growth of ryegrass areas 1 year or more old with the rest of the farm during winter 1985

\begin{tabular}{cccc}
\hline & & \multicolumn{2}{c}{ Rate of Growth kg/ha.day } \\
Renovated Pastures & Farm Average \\
\hline $25 / 4$ & $18 / 5$ & 31 & 28 \\
$19 / 5-4 / 6$ & $21^{\prime}$ & 22 \\
$5 / 6$ & $24 / 6$ & $28^{2}$ & 20 \\
$2 / 8$ & $-10 / 9$ & $28^{2}$ & 23 \\
& Average & 26 & 21 \\
\hline
\end{tabular}

based on 2 paddocks. 2 based on 5 paddocks.

TABLE 4. The costs of renovation for autumn 1985 (\$/ha).

\begin{tabular}{lcc}
\hline & \multicolumn{2}{c}{ Roundup } \\
& 5 litres/ha & $\begin{array}{c}\text { at } \\
\mathbf{2} \text { litres/ha }\end{array}$ \\
\hline Chemical & 152.00 & 61.00 \\
Contractor (drilling) & 50.00 & 50.00 \\
Seed & 59.00 & 59.00 \\
\cline { 2 - 3 } Total & $\$ 261.00$ & $\$ 170.00$ \\
\cline { 2 - 3 } & 268 & 268 \\
Less extra 67 kg MF @\$4/kg & $\$ 7$ & $\$ 98$ \\
\hline
\end{tabular}

\section{SUMMARY}

At this stage the new grass paddocks are providing more grass after three years than other equivalent paddocks on the farm. The benefit will, I hope, continue for longer than this. At this stage I will continue to renovate two paddocks each year as finance permits. The basic seed mix will continue to be Ellett ryegrass and Pitau white clover but I will try other species such as Pawera red clover which I wanted to use this last autumn but no seed was available.

In the district generally I have noted an interest in pasture renovation over the last two seasons and I can see that the Dairy Board will continue to be embarassed with the increase in production from the Northland area. 